\title{
DIFFERENT TEST OF ABNORMAL RETURN AND TVA BEFORE AND AFTER STOCK SPLIT ANNOUNCEMENT
}

\begin{tabular}{|c|c|}
\hline \multicolumn{2}{|c|}{$\begin{array}{c}\text { Ayu Putri Kukuh Pangesti }{ }^{1} \\
\begin{array}{c}\text { AUniversitas Islam Batik Surakarta, Indonesia } \\
\text { ayuputrikp@gmail.com }\end{array}\end{array}$} \\
\hline INFO ARTIKEL & ABSTRAK/ABSTRACT \\
\hline $\begin{array}{l}\text { Histori Artikel : } \\
\text { Tgl. Masuk : } 16 \text { Mei } 2019 \\
\text { Tgl. Diterima : } 21 \text { Agustus } 2019 \\
\text { Tersedia Online : } 30 \text { September } 2019 \\
\text { Keywords: } \\
\text { Stock Split, Abnormal Return, } \\
\text { TVA }\end{array}$ & $\begin{array}{l}\text { This study aims to determine whether there are } \\
\text { differences in abnormal return (AR) and trading } \\
\text { volume activity (TVA) between before and after the } \\
\text { announcement of a stock split. The data used in this } \\
\text { study are secondary data from the Indonesia Stock } \\
\text { Exchange (IDX). Sampling in this study used a } \\
\text { purposive sampling method. With certain criteria } \\
\text { obtained a sample of } 30 \text { companies. This study uses } \\
\text { event studies to determine the information content } \\
\text { contained in an event. Hypothesis testing conducted } \\
\text { in this study uses the normality test and paired sample } \\
\text { t-test. The results of testing the first hypothesis in this } \\
\text { study indicate that there is no difference in AR } \\
\text { between before and after the announcement of a stock } \\
\text { split. This happens because investors consider the } \\
\text { stock split announcement have no economic value } \\
\text { and prefer to allocate their funds to companies that are } \\
\text { truly able to provide a return. While in the second } \\
\text { hypothesis testing found the same thing that there is } \\
\text { no significant TVA difference between before and after } \\
\text { the announcement of the stock split. }\end{array}$ \\
\hline
\end{tabular}

\section{PENDAHULUAN}

Investasi di pasar modal mengandung unsur ketidakpastian karena risiko yang akan dihadapi. Dengan demikian, pengambilan keputusan investasi tidak hanya berdasarkan tingkat keuntungan yang diharapkan tetapi juga memperhitungkan besarnya resiko dalam pengambilan keputusan tersebut. Apabila mengharapkan keuntungan yang tinggi, maka resiko yang harus ditanggung akan tinggi pula. Untuk mengurangi risiko yang timbul dari investasi tersebut, investor membutuhkan informasi yang lengkap dan dapat menggambarkan kondisi pasar modal yang dapat dilihat dari reaksi pasar.

Reaksi pasar dapat diukur dengan menggunakan return tidak normal (abnormal return). Return tidak normal merupakan kelebihan dari return yang sesungguhnya terjadi terhadap normal return. Normal return merupakan return yang diharapkan oleh investor atau expected return. Dengan demikian return tidak normal (abnormal return) adalah selisih dari return yang sesungguhnya terjadi dengan return yang diharapkan (expected return). Return merupakan hasil yang diharapkan dari sebuah 
investasi. Indikator lain yang dapat digunakan untuk melihat ada atau tidaknya reaksi pasar terhadap suatu peristiwa adalah volume perdagangan saham. Untuk melihat pengaruh sebuah pengumuman terhadap volume perdagangan saham dapat diukur dengan menghitung trading volume activity (TVA). Trading volume activity (TVA) adalah perbandingan antara jumlah saham yang diperdagangkan pada periode tertentu dengan jumlah saham yang beredar pada periode tersebut. Jika terjadi kenaikan pada trading volume activty (TVA) dapat diartikan bahwa tingkat likuiditas saham tersebut meningkat. Begitu pula sebaliknya, jika trading volume activity menurun maka dapat diartika likuiditas saham tersebut menurun.

Pemecahan saham (stock split) adalah salah satu pengumuman yang diterbitkan perusahaan dan dapat dilihat kandungan informasinya dengan menggunakan metodologi event study. Sebuah perusahaan melakukan pemecahan saham (stock split) memiliki tujuan untuk menjaga harga saham tersebut tidak terlalu tinggi sehingga mencapai harga yang optimal untuk diperdagangkan dan meningkatkan likuiditas saham tersebut. Likuiditas suatu saham adalah cepat lambatnya suatu saham dapat diperjual belikan di bursa saham. Saham yang likuid berarti saham tersebut cepat laku terjual.

Dari uraian diatas, masalah yang dapat dirumuskan dalam penelitian ini adalah: (1) Apakah ada perbedaan Abnormal return sebelum dan sesudah pengumuman Stock split? (2) Apakah ada perbedaan Trading volume activity sebelum dan sesudah pengumuman Stock split? Manfaat dari penelitian ini adalah: (1) Bagi akademisi bermanfaat untuk pengembangan ilmu mengenai pasar modal dan sebagai referensi penelitian selanjutnya; (2) Bagi praktisi dapat digunakan sebagai informasi, kontribusi dan acuan dalam mengambil keputusan investasi di pasar modal dan memberikan masukan kepada perusahaan ketika akan melakukan stock split.

\section{KERANGKA TEORITIS DAN PENGEMBANGAN HIPOTESIS}

\section{Event Studies}

Event study merupakan studi yang mempelajari reaksi pasar terhadap suatu peristiwa yang infomasinya dipublikasikan sebagai suatu pengumuman. Event study dapat digunakan untuk menguji kandungan informasi (information content) dari suatu pengumuman dan dapat juga digunakan untuk menguji efisiensi pasar bentuk setengah kuat. Pengujian kandungan informasi dan pengujian efisiensi pasar bentuk setengah kuat merupakan dua pengujian yang berbeda. Studi peristiwa digunakan untuk melihat bagaimana reaksi pasar terhadap suatu peristiwa yang informasinya dipublikasikan. Peristiwa tersebut dapat berupa peristiwa ekonomi atau non ekonomi dan juga dapat berasal dari dalam perusahaan maupun dari luar perusahaan. Dari peristiwa tersebut dapat dilihat adakah abnormal return yang diperoleh pemegang saham. Selain itu, event study juga dapat digunakan sebagai alat untuk menguji kandungan informasi dari suatu peristiwa atau pengumuman.

\section{Stock Split}

Pemecahan saham (stock split) adalah memecah lembar saham menjadi $n$ lembar saham, dimana harga per lembar saham setelah stock split adalah sebesar $1 / n$ dari harga sebelumnya. Secara umum, stock split merupakan kebijakan perusahaan 
dalam memengaruhi jumlah saham yang beredar serta nilai nominal per lembar sahamnya. Perubahan dalam jumlah lembar saham yang beredar yang sebanding dengan perubahan nilai nominal per lembar saham tidak mengakibatkan adanya perubahan struktur modal perusahaan pada saat keputusan pemecahan saham.

\section{Abnormal Return}

Abnormal return adalah selisih antara tingkat keuntungan yang sebenarnya dengan tingkat keuntungan yang diharapkan. Abnormal return sering digunakan sebagai dasar pengujian efisiensi pasar. Pasar dikatakan efisien jika tidak satu pun pelaku pasar yang menikmati abnormal return dalam jangka waktu yang cukup lama. Akan tetapi, abnormal return dapat digunakan untuk melakukan penilaian kinerja surat berharga.

\section{Trading Volume Activity}

Volume perdagangan saham (trading volume activity) merupakan rasio antara jumlah lembar saham yang diperdagangkan pada waktu tertentu terhadap jumlah saham yang beredar pada waktu tertentu. Trading volume acivity saham adalah jumlah transaksi jual beli suatu saham tertentu pada waktu tertentu. Naiknya trading volume acivity merupakan bentuk kenaikan aktivitas jual beli yang terjadi di lantai bursa. Semakin tinggi jumlah penawaran dan permintaan suatu saham, maka akan semakin besar pula pengaruhnya terhadap fluktuasi harga saham tersebut di lantai bursa, dan semakin tinggi trading volume acivity sebuah saham menunjukkan bahwa saham tersebut semakin diminati masyarakat.

\section{Penelitian Sebelumnya}

Aduda dan Caroline (2010) menguji efek dari saham yang dipecah di Nairobi Stock Exchange dengan mempelajari sembilan perusahaan yang mengalami stock split di periode 2002-2008. Hasil penelitian menunjukkan bahwa secara umum, ada suatu peningkatan di volume perdagangan dari saham yang diperdagangkan ketika stock split tersebut diumumkan, terutama terjadi di hari sekitar tanggal stock split. Aktivitas perdagangan saham dilihat secara umum juga meningkat setelah saham yang dipecah dibandingkan dengan saham yang belum dipecah. Hernoyo (2013), meneliti mengenai pengaruh kebijakan pemecahan saham (stock split). Penelitian tersebut berjudul "Pengaruh Stock Split Announcement Terhadap Volume Perdagangan dan Return" Penelitian tersebut bertujuan untuk mengetahui pengaruh stock split announcement terhadap volume perdagangan dan return saham pada perusahaan yang melakukan stock split di Bursa Efek Indonesia periode 2005-2011. Dari hasil penelitian dapat diketahui bahwa terdapat pengaruh signifikan stock split announcement terhadap return saham dan tidak ada perbedaan yang signifikan pada ratarata volume perdagangan sebelum dan sesudah stock split announcement.

Damayanti, dkk (2014), meneliti mengenai pengaruh kebijakan pemecahan saham (stock split). Penelitian tersebut berjudul "Analisis Pengaruh Pemecahan Saham (Stock Split) Terhadap Tingkat keuntungan (Return) Saham dan Likuiditas Saham". Hasil penelitian menunjukkan bahwa peristiwa pemecahan saham tidak menyebabkan adanya perbedaan abnormal return saham sebelum dan sesudah peristiwa pemecahan saham, 
dan peristiwa pemecahan saham menyebabkan adanya perbedaan volume perdagangan saham sebelum dan sesudah pemecahan saham yang dilakukan oleh perusahaan yang go public di Bursa Efek Indonesia pada periode 2008-2013.

\section{Kerangka Berfikir dan Hipotesis}

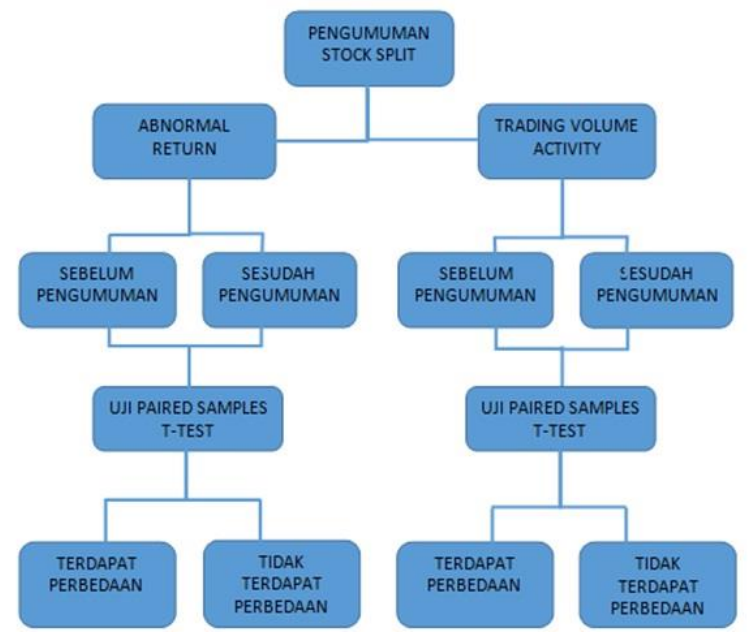

Gambar 1 Kerangka Berfikir

Perbedaan abnormal return antara sebelum dan sesudah pengumuman stock split

Penelitian yang dilakukan oleh Hernoyo (2013) mengemukakan bahwa terdapat perbedaan abnormal return saham sebelum dan setelah melakukan pemecahan saham (stock split).

$\mathbf{H}_{\mathbf{1}}$ : Terdapat perbedaan Abnormal Return sebelum dan sesudah pemecahan saham.

\section{Perbedaan trading volume activity sebelum dan sesudah pengumuman stock split \\ Penelitian yang dilakukan oleh Damayanti, dkk (2014) mengemukakan bahwa pemecahan saham menyebabkan adanya perbedaan volume perdagangan saham sebelum dan sesudah pemecahan saham yang dilakukan oleh perusahaan yang go public di}

Bursa Efek Indonesia pada periode 2008-2013.

$\mathrm{H}_{2}$ : Terdapat perbedaan Trading Volume Activity sebelum dan sesudah pemecahan saham.

\section{METODOLOGI PENELITIAN}

Penelitian ini menggunakan metode studi peritiwa (event study). Event study merupakan studi yang mempelajari reaksi pasar modal terhadap suatu peristiwa (event) yang informasinya dipublikasikan sebagai sebuah pengumuman, yaitu dengan melakukan analisis terhadap perubahan pada objek yang diteliti sehubungan dengan peristiwa yang telah terjadi. Variabel dan pengukuran yang digunakan adalah variabel dependen dan independen. Variabel dependen adalah (1) Abnormal return dan (2) Trading volume activity. Variabel independennya adalah stock split. Dalam penelitian ini peristiwa yang akan dianalisis adalah pengumuman pemecahan saham (stock split) yang dilakukan oleh emiten selama periode 2013-2016 pada Bursa Efek Indonesia (BEI). Sehingga sumber data penelitian ini adalah data sekunder dari saham-saham go public di Bursa Efek Indonesia (BEI) yang melakukan kebijakan pengumuman stock split pada tahum 2013-2016. Sampel diambil dengan menggunakan metode purposive sampling yaitu pengambilan sampel dengan kriteria tertentu. Instrumen dalam penelitian ini adalah dokumentasi. Metode analisis data penelitian ini menggunakan perhitungan abnormal return dan TVA yang kemudian diuji menggunakan paired sample t-test. 


\section{HASIL DAN PEMBAHASAN}

Data Diskriptif

Sampel awal dalam penelitian ini adalah perusahaan-perusahaan yang melakukan kebijakan stock split pada periode 2013-2016. Terdapat 55 perusahaan yang melakukan stock split selama tahun 2013-2016. Sampel awal tersebut kemudian disaring menjadi 30 perusahaan dengan menggunakan metode purposive sampling. Metode pengambilan sampel ini digunakan untuk menyaring sampel berdasarkan pada kriteriakriteria tertentu.

\section{Analisis Data}

Sebelum melakukan pengujian normalitas data dan pengujian hipotesis, perlu dilakukan analisis data yang diperoleh dari pengolahan data mentah yang telah didapat. Data yang diperoleh adalah data rata-rata abnormal return, dan rata-rata trading volume activity selama 15 hari pengamatan, yang mana pengamatannya adalah 7 hari sebelum tanggal stock split, tanggal stock split, dan 7 hari setelah tanggal stock split. Hasil analisis data adalah sebagai berikut:

\section{Tabel 1}

\section{Data Penelitian pada Tujuh Hari} Sebelum Stock Split dan Tujuh Hari Sesudah Stock Split

\begin{tabular}{lll}
\hline $\begin{array}{l}\text { Periode } \\
\text { Pengamata } \\
\mathbf{n}\end{array}$ & $\begin{array}{l}\text { Rata-rata } \\
\text { Abnormal } \\
\text { Return }\end{array}$ & $\begin{array}{l}\text { Rata-rata } \\
\text { Trading } \\
\text { Volume } \\
\text { Activity }\end{array}$ \\
\hline $\mathrm{T}+7$ & $-0,009092$ & 0,001183 \\
$\mathrm{~T}+6$ & 0,007090 & 0,001118 \\
$\mathrm{~T}+5$ & $-0,012526$ & 0,001742 \\
$\mathrm{~T}+4$ & $-0,013363$ & 0,001270 \\
$\mathrm{~T}+3$ & $-0,001282$ & 0,001833 \\
$\mathrm{~T}+2$ & 0,008876 & 0,001189 \\
$\mathrm{~T}+1$ & 0,015094 & 0,001406 \\
$\mathrm{~T}$ & $-0,134508$ & 0,001851 \\
$\mathrm{~T}-1$ & $-0,019140$ & 0,001467
\end{tabular}

\begin{tabular}{lll} 
T-2 & 0,002619 & 0,002051 \\
T-3 & 0,008371 & 0,001247 \\
T-4 & $-0,003831$ & 0,001475 \\
T-5 & 0,007754 & 0,002215 \\
T-6 & 0,005029 & 0,002589 \\
T-7 & 0,003759 & 0,001382 \\
\hline
\end{tabular}

Sumber Data diolah, 2019

\section{Uji Normalitas Data}

Uji normalitas digunakan untuk menguji apakah data yang diolah berdistribusi normal atau tidak dengan menggunakan pengujian One-Sample Kolmogorov-Smirnov Test. Berikut ini disajikan tabel 2 dan tabel 3 yang merupakan hasil pengujian normalitas data:

\section{Tabel 2}

Hasil Uji Normalitas Data Test rata-rata Abnormal Return Saham Sebelum dan Setelah Tanggal Pengumuman Stock Split

\begin{tabular}{lll}
\hline & $\begin{array}{l}\text { Rata-rata } \\
\text { Abnormal } \\
\text { Return } \\
\text { Sebelum }\end{array}$ & $\begin{array}{l}\text { Rata-rata } \\
\text { Abnormal } \\
\text { Return } \\
\text { Sesudah }\end{array}$ \\
\hline Jumlah Sampel & 30 & 30 \\
Nilai Probabilitas & 0,073 & 0,200 \\
Kriteria & 0,05 & 0,05 \\
Keterangan & Terdistribusi & Terdistribusi \\
& Normal & Normal \\
\hline
\end{tabular}

Sumber: SPSS, 2019 
Tabel 3

Hasil Uji Normalitas Data

Test rata-rata Trading Volume

Activity Saham Sebelum dan

Setelah Tanggal Pengumuman

Stock Split

\begin{tabular}{|c|c|c|}
\hline & $\begin{array}{l}\text { Rata-rata } \\
\text { TVA } \\
\text { Sebelum }\end{array}$ & $\begin{array}{l}\text { Rata-rata } \\
\text { TVA } \\
\text { Sesudah }\end{array}$ \\
\hline Jumlah Sampel & 30 & 30 \\
\hline Nilai Probabilitas & 0,200 & 0,200 \\
\hline Kriteria & 0,05 & 0,05 \\
\hline \multirow[t]{2}{*}{ Keterangan } & Terdistribusi & Terdistribus \\
\hline & Normal & i Normal \\
\hline
\end{tabular}

Sumber: SPSS, 2019

\section{Uji Hipotesis}

\section{Paired Samples T-Test}

Sebelum dilakukan pengujian, ditentukan terlebih dahulu hipotesis. HO diterima jika sig. > dari tingkat signifikansi a $(0,05)$, sedangkan $\mathrm{HO}$ ditolak atau $\mathrm{H} 1$ diterima jika sig. < dari tingkat signifikansi $\alpha(0,05)$.

\section{Tabel 4}

\section{Hasil Uji Paired Samples T-Test}

Rata-Rata Abnormal Return Sebelum dan Sesudah Periode Stock Split

\begin{tabular}{lllll} 
& $\begin{array}{l}\text { Rata } \\
-\end{array}$ & $\begin{array}{l}\text { Kriter } \\
\text { Rata }\end{array}$ & $\begin{array}{l}\text { Sig } \\
\text { Diteri } \\
\text { ma }\end{array}$ & $\begin{array}{l}\text { Keteran } \\
\text { gan }\end{array}$ \\
\hline $\begin{array}{l}\text { Rata-Rata } \\
\text { Abnormal }\end{array}$ & & & & \\
$\begin{array}{l}\text { Return } \\
\text { Sebelum }\end{array}$ & 0,00 & 0,3 & & $\begin{array}{l}\text { Tidak } \\
\text { dan }\end{array}$ \\
$\begin{array}{l}\text { Sesudah } \\
\text { Stock }\end{array}$ & 867 & 48 & 0,05 & $\begin{array}{l}\text { Ada } \\
\text { Perbed } \\
\text { aan }\end{array}$ \\
Split & & & & \\
\hline
\end{tabular}

Sumber: SPSS, 2019

Dari tabel 4 disimpulkan bahwa HO diterima. Maka dapat dikatakan bahwa tidak ada perbedaan abnormal return yang pada periode sebelum dan sesudah peristiwa stock split.

Tabel 5

Hasil Uji Paired Samples T-Test

Rata-Rata Trading Volume Activity Sebelum dan Sesudah Periode Stock Split

\begin{tabular}{lllll}
\hline & $\begin{array}{l}\text { Rata- } \\
\text { Rata }\end{array}$ & Sig & $\begin{array}{l}\text { Kriteri } \\
\text { a HO } \\
\text { Diteri } \\
\text { ma }\end{array}$ & $\begin{array}{l}\text { Keteran } \\
\text { gan }\end{array}$ \\
\hline $\begin{array}{l}\text { Rata- } \\
\text { Rata }\end{array}$ & & & & \\
TVA & & & & \\
$\begin{array}{l}\text { Sebel } \\
\text { um }\end{array}$ & 0,236 & 0,0 & 0,05 & $\begin{array}{l}\text { Tdak } \\
\text { Perbeda } \\
\text { dan }\end{array}$ \\
$\begin{array}{l}\text { Sesud } \\
\text { ah }\end{array}$ & & 84 & & an \\
Stock & & & & \\
Split & & & & \\
\hline
\end{tabular}

Sumber: SPSS, 2019

Berdasarkan tabel 5 disimpulkan bahwa $\mathrm{HO}$ diterima. Maka dapat dikatakan bahwa tidak ada perbedaan trading volume activity pada periode sebelum dan sesudah peristiwa stock split. dengan hasil ini dapat diartikan bahwa pasar tidak terlalu bereaksi dengan adanya kebijakan stock split yang dikeluarkan oleh perusahaan.

\section{KESIMPULAN}

Penelitian ini bertujuan untuk mengetahui pengaruh kebijakan stock split terhadap abnoral return dan trading volume activity pada perusahaan-perusahaan yang melakukan kebiajakan stock split di BEl pada periode tahun 2013 sampai dengan tahun 2016. Berdasarkan analisis dari 30 sampel perusahaan, dapat disimpulkan bahwa: (1) Tidak terdapat perbedaan yang signifikan antara rata-rata abnormal return sebelum dan sesudah peristiwa stock split. Hal tersebut terjadi karena investor menganggap bahwa pengumuman stock split tidak 
mengandung nilai ekonomis dan investor lebih memilih menginvestasikan dana mereka pada perusahaan yang benar benar mampu memberikan return yang tinggi. (2) Tidak terdapat perbedaan yang signifikan antara rata-rata trading volume activity sebelum dan sesudah peristiwa stock split. Dapat dilihat dari nilai signifikansi 0,084 yang lebih besar dari nilai probabilitas sebesar 0,05 .

Penelitian ini dilakukan dengan beberapa keterbatasan penelitian yang dapat mempengaruhi hasil penelitian. Keterbatasan-keterbatasan yang ada yaitu: (1) Hasil data tidak dapat digeneralisasikan untuk data dengan waktu berbeda; (2) Perusahaan yang menjadi sampel tidak dilihat dari klasifikasi industrinya; (3) Data yang digunakan adalah data sekunder yang mungkin terdapat kesalahan dalam memasukkan data yang berupa angkaangka.

Dari keterbatasan tersebut, diharapkan untuk penelitian selanjutnya agar dapat memperbaiki hal-hal berikut: Menambah periode penelitian sehingga lebih akurat; (2) Menambah variabel penelitian; (3) Menambah data primer seperti kuesioner yang ditujukan kepada pihak manajemen untuk mendukung data sekunder yang digunakan

\section{REFERENCES}

Aduda, Josiah Omollo dan Chemarum Caroline. 2010. Market Reaction to Stock Splits: Empirical Evidence From The Nairobi Stock Exchange. Dalam African Journal of Business \& Management, 1: h: 165-184.

Damayanti, N. L., Atmadja, A. T., Surya, N. A. (2014). Analisis Pengaruh Pemecahan Saham (Stock Split) Terhadap Tingkat Keuntungan (Return) Saham dan Likuiditas Saham. e-Journal S1 Ak Univesitas Pendidikan Ganesha Jurusan Akuntansi Program S1, Vol. 2.

Hartono, J. (2010). Teori Portofolio dan Analisis Investasi. Yogyakarta: BPFE.

Hernoyo, M. A. (2013). Pengaruh Stock Split Announcement Terhadap Volume Perdagangan dan Return. Management Analysis Journal, Vol. 2.

Saham OK. (2019). Kapitalisasi Pasar \& Saham Beredar. (http://www.sahamok.com/emite n/kapitalisasi-pasar). Diakses pada tanggal 3 April 2019.

Undang-Undang No. 8 Tahun 1995, Tentang Pasar Modal. Lembaran Negara Republik Indonesia Tahun 1995 No. 64.

Yahoo Finance. (2019). Historical Price.

(http://www.finance.yahoo.com). Diakses pada tanggal 2 April 2019. 